\title{
Helicobacter Pylori Infection in Cases of Hyperemesisgravidarum; Updates
}

\author{
Sameh S Sadek ${ }^{1}$, M Elmahdy ${ }^{1 *}$, A Elmarsafawy ${ }^{1}$, D Elkafash ${ }^{2}$ and Azza Elhenawy ${ }^{1}$ \\ ${ }^{1}$ Department of Obstetrics and Gynecology, Alexandria University, Egypt \\ ${ }^{2}$ Department of Clinical and Chemical Pathology, Alexandria University, Egypt
}

Submission: March 16, 2017; Published: May 03, 2017

*Corresponding author: Mohamed Elmahdy, Department of Obstetrics and Gynecology, Alexandria University, Egypt,

Email: mahdy_moh@yahoo.com

\begin{abstract}
Background: One of the serious problem affecting pregnant females is Hyperemesis gravidarum. Different theories were suggested. But the main etiology is still unknown

Objectives: To determine the incidence of Helicobacter pylori infection in cases of hyperemesis gravidarum.

Patients and methods: case control study of 80 cases (40 case of HEG) and (40 case of normal pregnant females. Determination of Helicobacter pylori antibodies were done in serum and stool for the two studied groups.

Results: $75 \%$ of cases of HEG were positive of Helicobacter pylori in stool samples and $37.50 \%$ of normal pregnant females. These results were statistically significant ( $\mathrm{p}=0.001$ ). The prevalence of $\mathrm{HpIgG} \mathrm{AB}$ and HpSAB was $77.5 \%$ in the patients group with $\mathrm{HEG}$, and $55.0 \%$ in control studied group $(\mathrm{P}=0.05)$. There was a significant difference between HEG cases and normal pregnancy as regards serum sodium $(0.042)$.

Conclusions: Infection by helicobacter pylori may be one of the risk factors for HEG. Helicobacter pylori AB in both serum and stool is higher in HEG cases than in normal pregnant females.
\end{abstract}

Keywords: HEG; H. Pylori; Pregnancy

\section{Introduction}

Approximately 50\% of pregnant women suffer from nausea and vomiting. And in about of $80 \%$ these symptoms begin between the $4^{\text {th }}$ and $7^{\text {th }}$ week after the last menstrual period [1].

On the other side, one of the complications occurring during pregnancy is Hyperemesis gravidarum (HG). Its symptoms include intractable nausea, vomiting, and dehydration and occur in $0.5-2.0 \%$ of pregnant women $[2,3]$ usually in the $1^{\text {st }}$ trimester [4]. In case of severe or inadequately treated hyperemesis gravidarum, another symptoms may be appear such as: [2] Loss of $5 \%$ or more of pre-pregnancy body weight, Dehydration, causing ketosis [4] and Metabolic imbalances which may results in metabolic ketoacidosis [2].

The etiology of $\mathrm{HG}$ is most likely to be multifactorial. Women with HG are more likely to be younger, primiparous and with Female infant sex while Body mass index, smoking, socioeconomic status and Paternal genes didn't not affect the occurrence of $\mathrm{HG}$ [5].
Helicobacter pylori which is also named Campylobacter pylori, is a Gram-negative, microaerophilic bacterium found in the stomach, and may be in other parts of the body, such as the eye $[6,7]$.

Nashaat et al. [8] suggested that hyperemesis gravidarum may be caused due to chronic infection with Helicobacter pylori [8]. On the other hand some researchers failed to assign a relation between the onset and the chronicity of the infection and the occurrence and the severity of HG [9].

Our objectives were to determine the possible relationship between Helicobacter pylori infection and the occurrence of $\mathrm{HG}$ in pregnant women during the first three month of pregnancy.

\section{Materials and Methods}

This study was approved by national research ethics committee and was performed according to the ethical standards shown in the 1964 Declaration of Helsinki and its comparable ethical standards. 


\section{Informed consent}

Written informed consent was obtained from all women included in the study." It is a case control study carried out on 80 pregnant females attending the antenatal care clinic of El Shat by Maternity University Hospital in the period from April 2015 till March 2016.

They were divided into two studied groups:

Group 1: Forty (50\%) pregnant females complaining of hyperemesis gravidarum (cases) and group 2: Forty (50\%) normal pregnant females (controls).

Inclusion criteria: all pregnant women included in the study were pregnant with gestational age from 5 to 15 weeks and complaining from symptoms of severe vomiting $(\geq 3$ times a day) not responding to traditional treatments, weight loss ( $\geq 5 \%$ of body weight); hyperemesis gravidarum and presence of ketonuria. While the control group were pregnant women with the same gestational age but without manifestation of HG. Both groups in the study were comparable as regards age, obstetric history, and gestational age.

Exclusion criteria: Patients with history of thyroid disorders, multiple pregnancy, psychological diseases, gestational trophoblastic disorders, hepatobiliary disorders and gastric or any intestinal disease.

Women eligible for the study were informed about the nature of the study before blood samples and stool specimens were taken.

\section{Assessment of serum H pylori IgG antibody}

Samples were obtained by venous blood sample and centrifuged at 3000rpm for 10 minutes. Serum was stored at -30 ${ }^{\circ} \mathrm{C}$ till the analysis. H pylori IgG antibody (HpIgGAb) was assessed by enzyme-linked immunosorbent assay (ELISA) kits. Results were measured by BioTek ELx 800 ELISA reader. Results were assigned as positive, negative, and equivocal. The lower limit for a "positive" result was $\geq 1.00$ and $\leq 0.9$ as a negative test. Values ranging from 0.91-0.99 was assigned as equivocal.

\section{Determination of $h$ pylori stool antigen}

Stool samples from each woman were put into clean cups and stored at $-30{ }^{\circ} \mathrm{C}$ until assessment. All stool samples were assessed for $\mathrm{H}$ pylori stool antigen (HpSA) by HpSA enzymelinked immune sorbent assay (Diagnostic Bio Probessrl, Milano, Italy) according to the manufacturer's manual. positive result was considered as any value $\geq 0.298$ at optical density of $450 \mathrm{~nm}$ and negative results were $<0.298$.

\section{Statistical analysis of the data}

Data were introduced to the computer and processed using IBM SPSS software package version 20.0. Qualitative data were presented using number and percentage. Quantitative data were presented using range (minimum and maximum), mean, standard deviation and median. 5\% level was chosen as Significance for results.

We used the following statistical tests:
A. Chi-square test: in categorical variables
B. Monte Carlo correction: Correction for chi-square when more than $20 \%$ of the cells have expected count less than 5
C. Student t-test: in normally quantitative variables.
D. Z for Mann Whitney test: in abnormally quantitative variables.

\section{Results}

Forty (50\%) pregnant females complaining of hyperemesis gravidarum (cases) and forty (50\%) normal pregnant females (controls) were enrolled in the study during the period from April 2015 till March 2016. There was no cancelled or dropped cases from the study.

The ages of the women in both groups ranged from 20 to 35years, they were more or less matched for age;the mean age of patients was $27.50 \pm 4.66$ while that of the controls was 26.95 \pm 4.71 (Table 1).

Table 1: Comparison between the two groups according to demographic data.

\begin{tabular}{|c|c|c|c|c|}
\hline & Cases & Control & T & P \\
\hline Age (years) & & (n= 40) & & \\
\hline Min.-Max. & $20.0-35.0$ & $20.0-35.0$ & 0.525 & 0.601 \\
\hline Mean \pm SD. & $27.50 \pm 4.66$ & $26.95 \pm 4.71$ & & \\
\hline Median & 27.5 & 26.5 & & \\
\hline Weight (kg) & & & & \\
\hline Min.-Max. & $42.0-74.0$ & $57.0-83.0$ & $5.461^{*}$ & $<0.001^{*}$ \\
\hline Mean \pm SD. & $60.40 \pm 10.45$ & $71.70 \pm 7.88$ & & \\
\hline Median & 59.5 & 73.5 & & \\
\hline
\end{tabular}

T: Student t-test

*: Statistically significant at $p \leq 0.05$

Body weight was significantly lower among patients as compared to controls (Table 1). There was no significant difference between patients and controls according to obstetric history; gravidity, parity and abortion.

A significant difference between patient and controls according to vital signs including systolic blood pressure, diastolic blood pressure, and pulse rate (Table 2). 
Table 2: Comparison between the two groups according to vital signs

\begin{tabular}{|c|c|c|c|c|}
\hline & Cases & Control & T & P \\
\hline Systolic & $\mathbf{n = 4 0 )}$ & $(\mathbf{n}=\mathbf{4 0 )}$ & & \\
\hline Min. - Max. & $\begin{array}{c}80.0- \\
100.0\end{array}$ & $100.0-130.0$ & $13.933^{*}$ & $<0.001^{*}$ \\
\hline Mean \pm SD. & $89.13 \pm 6.97$ & $116.0 \pm 10.01$ & & \\
\hline Median & 90 & 117.5 & & \\
\hline Diastolic & & & & \\
\hline Min. - Max. & $50.0-75.0$ & $70.0-80.0$ & $9.985^{*}$ & $<0.001^{*}$ \\
\hline Mean \pm SD. & $60.75 \pm 7.81$ & $75.0 \pm 4.53$ & & \\
\hline Median & 60 & 75 & & \\
\hline Pulse & & & $7.862^{*}$ & $<0.001^{*}$ \\
\hline Min. - Max. & $75.0-96.0$ & $71.0-84.0$ & & \\
\hline Mean \pm SD. & $86.45 \pm 7.32$ & $76.52 \pm 3.19$ & & \\
\hline Median & 87.5 & 76 & & \\
\hline
\end{tabular}

\section{t: Student t-test}

\section{*: Statistically significant at $p \leq 0.05$}

H. pylori stool antigen (HpSA) was 77.5\% (31 of 40) in the patients with HEG, and $55.0 \%$ (22 of 40 ) in controls $(\mathrm{P}=0.05 ; \chi 2$ $=4.528$ ). These results are considered as significant one Figure 1 .

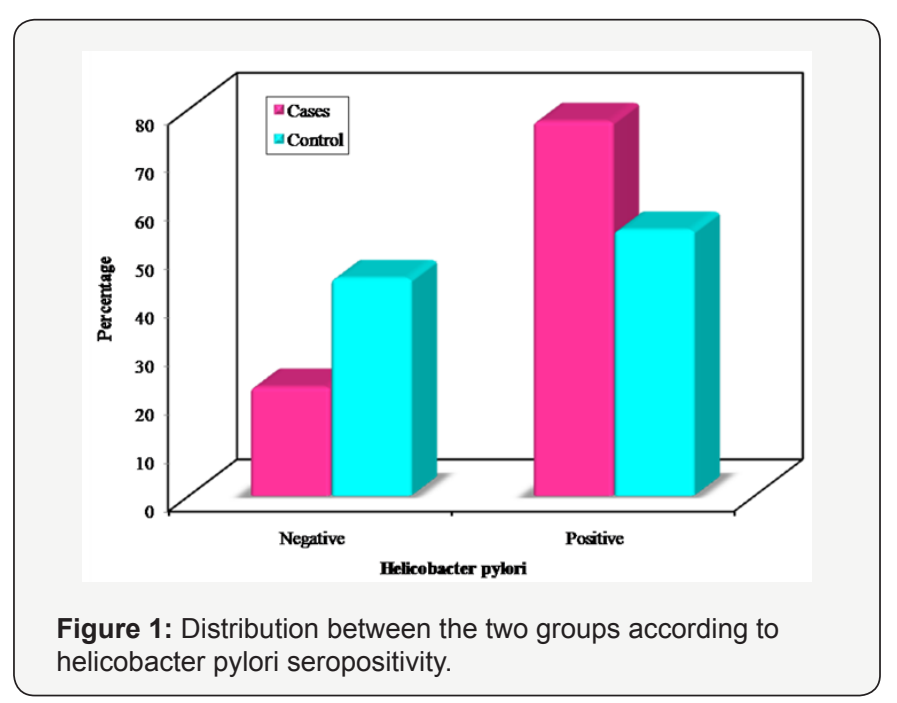

Helicobacter pylori in stool samples were 30 positive of 40 cases with $75 \%$ and 15 positive of 40 controls with $37.50 \%$. These results were statistically significant difference $(p=0.001)$ Figure 2.

Regarding the prevalence of H. Pylori, it didn't differ with age, gravidity and parity in cases with HEG with positive or negative helicobacter pylori infection.

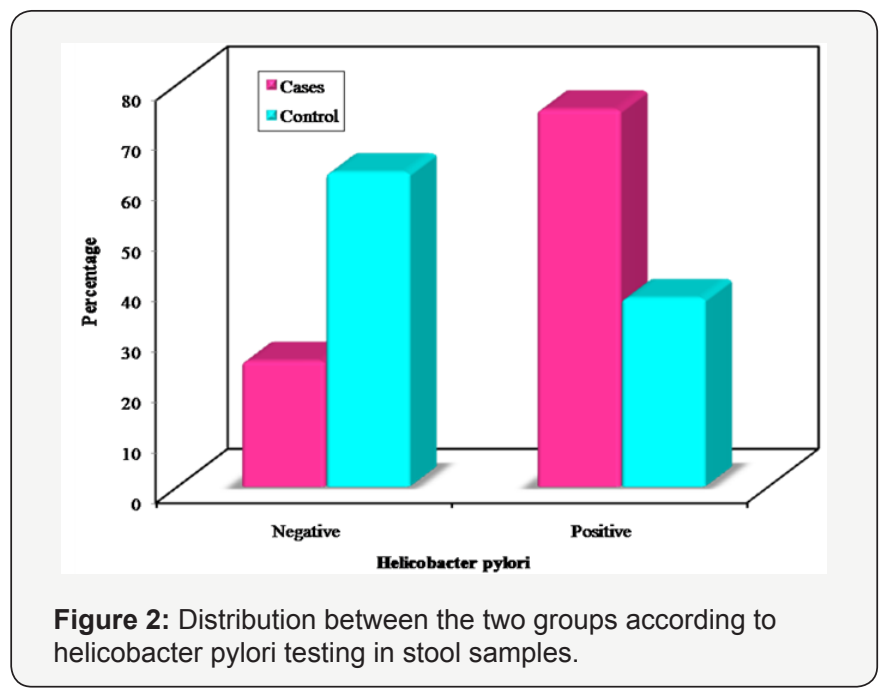

There was a significant difference between cases with HEG and control groups as regards serum sodium levels while there was no statistical difference as regards serum potassium and serum bilirubin (Table 3).

Table 3: Serum sodium, potassium and total serum bilirubin levels in the cases and the control Z: Z for Mann Whitney test.

\begin{tabular}{|c|c|c|c|c|}
\hline & HEG & & $\begin{array}{c}\text { Test of } \\
\text { sig. }\end{array}$ & $\mathbf{P}$ \\
\hline & $\begin{array}{c}\operatorname{Cases}(n= \\
40)\end{array}$ & $\begin{array}{c}\text { Control }(n= \\
40)\end{array}$ & & \\
\hline \multicolumn{5}{|l|}{ Serum sodium } \\
\hline \multicolumn{5}{|l|}{ Meq/L } \\
\hline Min. - Max. & $124-139$ & $129-140$ & $\mathrm{t}=0.201$ & $0.042^{*}$ \\
\hline Mean \pm SD. & $129.6 \pm 6$ & $134 \pm 4.15$ & & \\
\hline Median & 128 & 131 & & \\
\hline \multicolumn{5}{|l|}{$\begin{array}{c}\text { Serum } \\
\text { potassium }\end{array}$} \\
\hline \multicolumn{5}{|l|}{ Meq/L } \\
\hline Min. - Max. & $1.5-4.2$ & $3.6-5.1$ & $\mathrm{t}=0.306$ & 0.052 \\
\hline Mean \pm SD. & $3.2 \pm 1.78$ & $4.61 \pm 1.45$ & & \\
\hline Median & 2 & 4 & & \\
\hline \multicolumn{5}{|l|}{$\begin{array}{c}\text { Serum total } \\
\text { bilirubin mg/ } \\
\text { dl }\end{array}$} \\
\hline Min.-Max. & $0.3-2.0$ & $0.2-1.2$ & $\mathrm{t}=0.826$ & 0.409 \\
\hline Mean \pm SD. & $0.9 \pm 0.48$ & $6 \pm 0.31$ & & \\
\hline Median & 1 & 0.7 & & \\
\hline
\end{tabular}

t: Student t-test.

\section{Discussion}

$50 \%$ of pregnant women suffer from Vomiting, and $25 \%$ suffer from nausea [10]. However, only $0.3-1.5 \%$ is the 
incidence of HEG [11] its cause is theoretical, and one of its reasons is Helicobacter pylori (H. pylori). H. pylori was first discovered in the stomachs of patients with gastritis and ulcers in 1982 [12]. H. pylori is a helix-shaped (classified as a curved rod, not spirochaete) Gram-negative microaerophilic bacterium [13]. This study was targeted to determine the relation between H.pylori infection and HEG.

Rate of H. pylori sero positivity in hyperemetic patients was significantly higher $(77.5 \%)$ compared to the control group (55.0\%), $\mathrm{p}=0,058$.

Frigo et al. [14] found that $90.5 \%$ of female suffering from HG were positive for serum $H$. pylori A Bif compared to $46.5 \%$ of the normal pregnant group. Another study showed that females with HG had positive serum H. pylori (HP) AB in $92 \%$ of them as and it was $45 \%$ in the normal women group [15]. On the other hand two other researchers concluded that there was no correlation between HG and serum H. pylori AB, one conducted USA [16] and the other done by Berker et al. [17] from Turkey. Also, Shirin Rafie et al. [18] concluded that there was no association between HEG and H.P sero positivity. Golberg D et al. [19] and Irene Sandven et al. [20] found that there was a positive relation between HG and H pylori seropositivity.

Salimi et al. [21] detect Positive serum H. pylorilg G antibody in $88.9 \%$ of the patients in the test group vs. $40.7 \%$ of the control group $(\mathrm{P}<0.001)$. Although more patients with $\mathrm{HG}$ were seropositive for $H$. pylori infection than control studied group, The correlation between seropositivity for $H$. pylori and the time of onset or duration of HG symptoms were not able to be demonstrated. Although H. pylori infection may be an important factor in causing HG, it may not represent the only cause of the disease.

On the other hand Vikanes et al. [22] reported that $H$. pylori exposure was not significantly associated with severe HG among immigrant women in Norway, By investigating H. pylori exposure by IgG seropositivity, VacA and CagA seropositivity or by the detection of $H$. pylori antigens in stool. These results may show a weakness in the association between $H$. pylori and HG previous expectations, especially in populations with high incidence of $H$. pylori infection.

Our results were comparable to the results found in previous studies, and showed that there is an association between HEG and H. Pylori infection. H. pylori infection is one of the factor that cause GIT disturbance, vomiting, and nausea in general population. But, H. Pylori infection determined by the seropositivity for its antibodies is also, prevalent in asymptomatic population as found by Sarker et al. [23] They found the high seroprevalence of vacA- and cagA- positive virulent $\mathrm{H}$. pylori strains in an asymptomatic paediatric population indicate that such strains are common in this population and may cause characteristic $H$. pylori infection in Bangladesh. So, geographical distribution, age, general condition of the female and patient susceptibility may be confounding factors for the associations of H. pylori infection with sever HEG cases.

\section{Conclusion}

H. pylori infection is conducted with severe form of HEG and may be listed as one of the risk factors for sever HEG.

\section{Acknowledgement}

To clinical pathology laboratory team due to their assistance.

\section{Conflict of interest}

There is no conflict of interest

\section{Ethical approval}

This article does not contain any studies with human participants or animals performed by any of the authors.

\section{Informed consent}

Informed consent was obtained from all individual participants included in the study.

\section{References}

1. Niebyl JR (2010) Nausea and vomiting in pregnancy. N Engl J Med 363: 1544-1550.

2. Summers A (2012) Emergency management of hyperemesis gravidarum. Emerg Nurse 20(4): 24-28.

3. Goodwin, TM (2008) Hyperemesis gravidarum. Obstetrics and gynecology clinics of North America 35 (3): 401-417.

4. Ahmed KT, Almashhrawi AA, Rahman RN, Hammoud GM, Ibdah JA et al. (2013) Liver diseases in pregnancy: diseases unique to pregnancy. World J Gastroenterol 19(43): 7639-7646.

5. Matthews DC, Syed AA (2011) The role of TSH receptor antibodies in the management of Graves' disease. Eur J Intern Med 22(3): 213-216.

6. Giusti C (2004) Association of Helicobacter pylori with central serous chorioretinopathy: Hypotheses regarding pathogenesis. Medical Hypotheses 63(3): 524-527.

7. Ahnoux-Zabsonre A, Quaranta M, Mauget-Faÿsse M Prévalence de l' Helicobacter pylori dans la choriorétino pathieséreusecentraleetl' épithéliopathierétinienne diffuse [Prevalence of Helicobacter pylori in central serous chorioretinopathy and diffuse retinal epitheliopathy: a complementary study]. Journal Françaisd'Ophtalmologie (in French) 27(10): 1129-1133.

8. Nashaat EH, Mansour GM (2010) Helicobacter pylori and Hyperemesis Gravidarum Continuous Study (2). Nature Sci 8(8): 22-26.

9. Sandven I, Abdelnoor M, Nesheim BI, Melby KK (2009) Helicobacter pylori infection and hyperemesis gravidarum: a systemic review and meta -analysis of case-control studies. Acta Obstet Gynecol Scand 88(11): 1190-1200.

10. Jennifer NR (2010) "Nausea and Vomiting in Pregnancy". New England Journal of Medicine 363(16): 1544-1550.

11. Sheehan P (2007) Hyperemesis gravidarum--assessment and management. Aust Fam Physician 36(9): 698-701.

12. The Nobel Prize in Physiology or Medicine (2005).

13. Olson JW, Maier RJ (2002) Molecular hydrogen as an energy source for Helicobacter pylori. Science 298 (5599): 1788-1790. 
14. Frigo P, Lang C, Reisenberger K, Kolbl H, Hirschl AM (1998) Hyperemesis gravidarum associated with Helicobacter pylori seropositivity. Obstetrics \& Gynecology 91(4): 615-617.

15. Koçak I, Akcan Y, Üstün C, Demirel C, Cengiz L, et al. (1999) Helicobacter pylori seropositivity in patients with hyperemesis gravidarum. Am J Med Sci 66(3): 251-254.

16. Jacobson GF, Autry AM, Somer-Shely TL, Pieper KL, Kirby RS (2003) Helicobacter pylori seropositivity and hyperemesis gravidarum. J Reprod Med 48(8): 578-582.

17. Berker B, Soylemez F, Cengiz SD, Kose SK (2003) Serologic assay of Helicobacter pylori infection. Is it useful in hyperemesis gravidarum? The Journal of Reproductive Medicine 48(10): 809-812.

18. Tari RS (2015) Hyperemesis Gravidarum. Obstet Gynecol Tehran Univ Med J 73(3): 182-191.

19. Golberg D (2007) Hyperemesis gravidarum and Helicobacter pylori infection: a systemic review. Obstet Gynecol 110(3): 695-703.
20. Sandven I (2008) Hyperemesis gravidarum and Helicobacter pylori infection epidemiology. European Journal of Epidemiology 34(3): 491498.

21. Salimi-Khayati A, Sharami H, Mansour-Ghanaei F, Sadri S, Fallah MS (2003) Helicobacter pylori aeropositivity and the incidence of hyperemesis gravidarum. Med Sci Monit 9(1): CR12-CR15.

22. Vikanes AV, Støer NC, Gunnes N, Grjibovski AM, Samuelsen SO, et al. (2013) Helicobacter pylori infection and severe hyperemesis gravidarum among immigrant women in Norway: a case-control study. Eur J Obstet Gynecol Reprod Biol 167(1): 41-46.

23. Sarker SA, Nahar S, Rahman M, Bardhan PK, Nair GB, et al. (2004) High prevalence of cagA and vacA seropositivity in asymptomatic Bangladeshi children with Helicobacter pylori infection. Acta Paediatr 93(11): 1432-1436

\section{Your next submission with Juniper Publishers} will reach you the below assets

- Quality Editorial service

- Swift Peer Review

- Reprints availability

- E-prints Service

- Manuscript Podcast for convenient understanding

- Global attainment for your research

- Manuscript accessibility in different formats ( Pdf, E-pub, Full Text, Audio)

- Unceasing customer service

Track the below URL for one-step submission https://juniperpublishers.com/online-submission.php 